\title{
Symptomatic epidural lipomatosis in ectopic Cushing's syndrome
}

\author{
Alexander G L Bodelier, Wim Groeneveld ${ }^{1}$, Antonius N van der Linden ${ }^{2}$ and Harm R Haak \\ Departments of Internal Medicine and Endocrinology, ${ }^{1}$ Neurology and ${ }^{2}$ Radiology, Máxima Medical Centre, The Netherlands, PO Box 90052 , \\ 5600 PD Eindhoven, The Netherlands \\ (Correspondence should be addressed to A Bodelier; Email: a.bodelier@mmc.nl)
}

\begin{abstract}
We report a case of spinal epidural lipomatosis (SEL) caused by ectopic Cushing's syndrome and give a review of the literature. The most common cause of SEL is prolonged therapy with glucocorticoids, only a very few cases are related to endogenous Cushing's syndrome. The pathophysiological mechanism is not clear but there is a possible role for the autonomic nervous system in the stimulation of growth of epidural fat. Severe neurological symptoms which indicate myelopathy and radiculopathy can occur, but there is often a delay in diagnosis because the non-specific initial symptoms are not recognized. The epidural fat is mostly located in the thoracic and lumbar region. Magnetic resonance imaging can establish the diagnosis rapidly. In patients with severe neurological symptoms, surgical decompression of the myelum and removal of the epidural fat is the treatment of choice. Most patients have partial or complete recovery of neurological deficits after surgical treatment or after discontinuing glucocorticoid therapy; mild cases can also be treated conservatively. Routine imaging for the detection of epidural-located lipomatosis in patients at risk is probably useful.
\end{abstract}

European Journal of Endocrinology $151765-769$

\section{Introduction}

Spinal epidural lipomatosis (SEL) is an excessive fat deposition in the spinal canal which can lead to compression of nervous structures. SEL is a rare but welldocumented complication of long-term glucocorticoid therapy with more than 50 reported cases in the literature. Only a very few cases describe SEL related to endogenous Cushing's syndrome. We present a patient with SEL related to the ectopic Cushing's syndrome. The literature on SEL is reviewed and possible pathophysiological mechanisms are considered. In view of the possibly severe neurological deficits and therapeutic consequences, SEL should be considered in all patients on steroid therapy and with endogenous Cushing's syndrome who present with symptoms of spinal cord or cauda equina compression, or even vague muscle complaints.

\section{Case report}

A 30-year-old man was admitted to our department for evaluation of hypertension and hypokalemia. He had used combination therapy with beta-blocker/thiazide diuretic for several months and had recently switched to angiotensin-converting enzyme (ACE)-inhibitor therapy. He suffered from polydipsia and had progressive pain and edema in both legs. There was no significant weight gain. On physical examination he was found to have a moonface, a buffalo hump, acne and centripetal obesity. His abdomen was distended and painful in the left upper quadrant. Blood pressure at that time was $140 / 100 \mathrm{mmHg}$. His body mass index (BMI) measured $24 \mathrm{~kg} / \mathrm{m}^{2}$. We considered Cushing's syndrome, possibly due to adrenocortical carcinoma, based on the Cushing's stigmata combined with the distended and painful left upper quadrant of the abdomen. Computed tomography (CT) scanning showed prominent adrenal glands but no adrenocortical tumor mass. Routine laboratory tests showed a glucose level of $16.7 \mathrm{mmol} / \mathrm{l}$ and a decreased level of potassium $(3.3 \mathrm{mmol} / \mathrm{l})$. Serum cortisol at $1500 \mathrm{~h}$ was increased to $2.34 \mu \mathrm{mol} / \mathrm{l}$, plasma adrenocorticotropic hormone (ACTH) was $71 \mathrm{pmol} / \mathrm{l}$ (normal $1.5-9 \mathrm{pmol} / \mathrm{l}$ ); 24-h urinary excretion of cortisol was markedly elevated at $20079 \mathrm{nmol}$. After administering $7 \mathrm{mg}$ i.v. dexamethason, cortisol and ACTH levels were suppressed to $1.44 \mu \mathrm{mol} / \mathrm{l}$ and $32 \mathrm{pmol} / \mathrm{l}$ respectively. Magnetic resonance imaging (MRI) of the pituitary region did not reveal a pituitary tumor. Levels of ACTH sampled from the left $(134 \mathrm{pmol} / \mathrm{l})$ and right (144 pmol/l) petrosal vein showed no substantial difference to the internal jugular vein $(130 \mathrm{pmol} / \mathrm{l})$ and peripheral forearm vein (124 pmol/l). After injection of corticotropinreleasing hormone, no stimulation of ACTH levels was observed in the left $(170 \mathrm{pmol} / \mathrm{l})$ and right (152 pmol/l) petrosal veins. An extrapituitary source of ACTH was suspected. Somatostatin receptor scintigraphy (Fig. 1) 


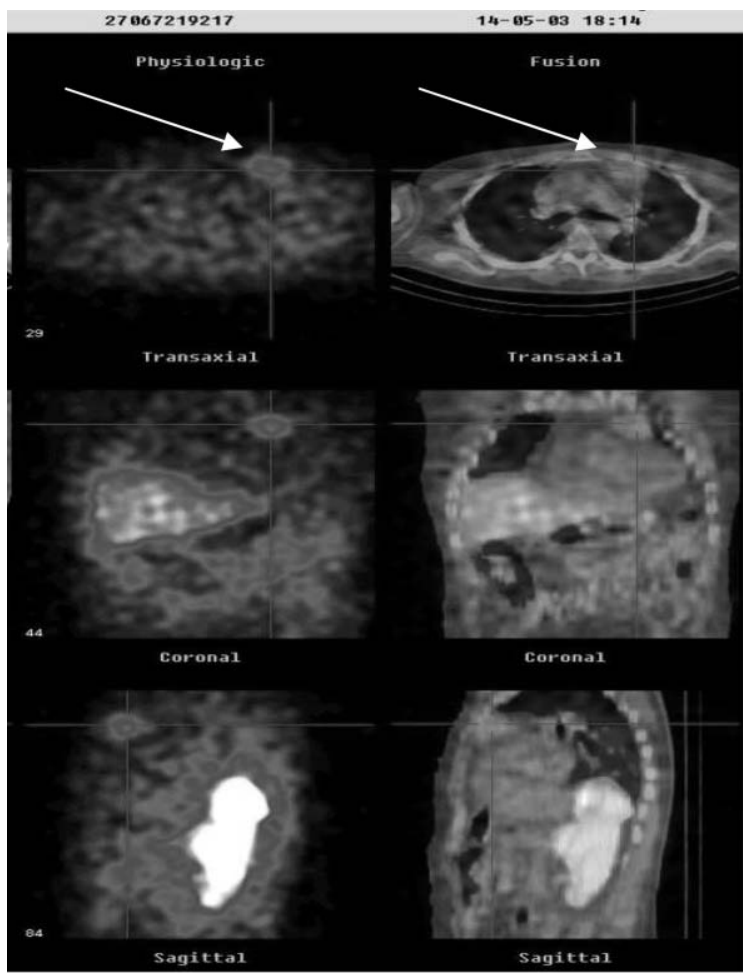

Figure 1 Somatostatin receptor scintigraphy and CT scan. The arrow on the left shows pathological enhancement in the upper mediastinum, the arrow on the right indicates tumor mass visualized with CT scanning.

and subsequent CT scanning visualized a $4 \mathrm{~cm}$ tumor mass in the upper mediastinum. Fine-needle aspiration was performed and a neuroendocrine tumor was suspected. During the diagnostic work-up our patient rapidly developed lower back pain, progressive weakness in both legs and diminished pain perception below the levels of Th3-Th4 dermatomes. MRI of the thoracolumbar spine was performed which showed a peridural lipomatosis from the first to the tenth thoracic vertebra with myelum compression, a diffuse osteoporotic spine and a compression fracture of the Th10 vertebral body (Figs 2a and 3a). The epidural fat thickness was $14 \mathrm{~mm}$ at Th6 level in sagittal view.

Because of grade 4 paresis of his lower extremities the patient became wheelchair dependent. Decompressive laminectomy with debulking of the epidural fat was initially considered but thought too great a risk of spine instability because of extensive osteoporosis and subsequent risk of further damaging the myelum. The hypercortisolism was treated, while awaiting the definitive surgical treatment, with ketoconazole in a maximum dosage of $600 \mathrm{mg}$ twice a day and metyrapone $750 \mathrm{mg}$ three times a day. Cortisol levels normalized within 1.5 months. A subsequent smaller dosage of antihypertensive medication was required and insulin therapy could gradually be diminished and eventually stopped. During this period no clinical improvement or deterioration of his neurological deficits occurred.
The ACTH-producing tumor in the upper mediastinum was resected via sternotomy and was diagnosed as atypical thymic carcinoid. The histological diameter of the tumor was $4.5 \mathrm{~cm}$. The diagnosis of atypical carcinoid was based on histological characteristics with central necrosis and multiple mitoses according to the 1999 WHO definition. No metastatic lymph nodes were present. Additional radiotherapy was performed. Within 3 months after surgery his condition and symptoms significantly improved and gradually he regained mobility. After 6 months he walked without appliances and went to work on a bike. Follow-up radiological studies showed a significant reduction in the amount of epidural fat (Figs $2 \mathrm{~b}$ and $3 \mathrm{~b}$ ), $8 \mathrm{~mm}$ thickness at Th6 level vs $14 \mathrm{~mm}$ before treatment. The Cushing's syndrome is in complete remission. Glucocorticoid supplementation could be stopped 8 months after surgery. Thymic carcinoid tumors can be an unusual presentation of the genetic syndrome multiple endocrine neoplasia (MEN) type 1 which is characterized by neoplasia of the parathyroid, pituitary and pancreatic islet cells. Our patient had no family history of endocrine tumors and there was no clinical, biochemical or radiological evidence for the MEN 1 syndrome.

\section{Discussion}

SEL is defined as an abnormal increase in the amount of non-encapsulated fat within the epidural space of the spinal canal. Compression of the spinal cord or nerve roots can lead to neurological symptoms such as muscle weakness, sensory loss and abnormal reflexes. The frequency of this excessive fat accumulation in the epidural space is unknown. SEL as a complication of endogenous Cushing's disease or syndrome is very rare. We found five additional cases in the literature $(1-5)$; the characteristics of these cases are shown in Table 1. In 1992, Noël et al. (1) reported a 35-yearold patient with SEL and an adrenal tumor. DumontFischer et al. (2) documented a similar case in 2002. The first case of SEL caused by ectopic ACTH production was described by Koch et al. in 1999 (3). The majority of case reports on SEL are in patients receiving long-term corticosteroid therapy $(6-14)$. Idiopathic lipomatosis has been described, mostly in patients with marked obesity $(4,6)$. SEL caused by local epidural corticosteroid injections has also been reported (15). The pathogenesis of this possible harmful condition is not fully understood. It is thought that the pre-existing epidural fat responds to the excess of steroids by progressive hypertrophy in a similar manner to the centripetal fat in Cushing's disease $(6,15)$. Exogenous glucocorticoid administration seems to be the major cause of symptomatic SEL. The underlying disorders in patients with SEL for which corticosteroid therapy was indicated are very heterogenous and include systemic lupus erythematosus, rheumatoid arthritis, chronic active hepatitis, renal and cardiac 
$\mathbf{a}$

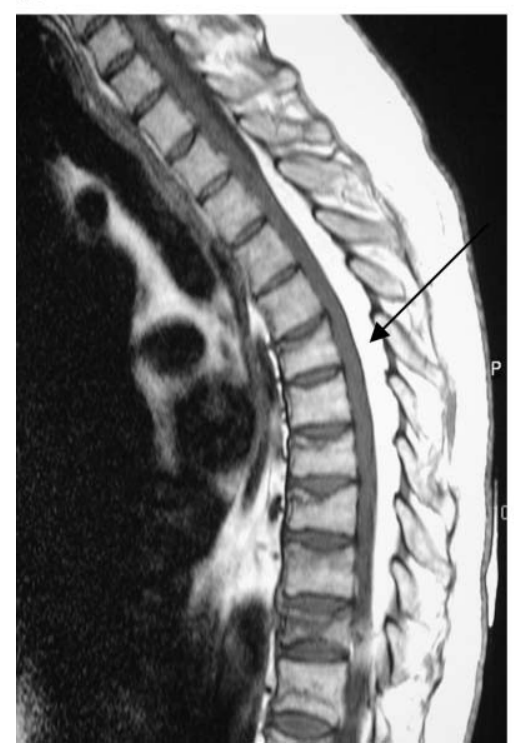

b

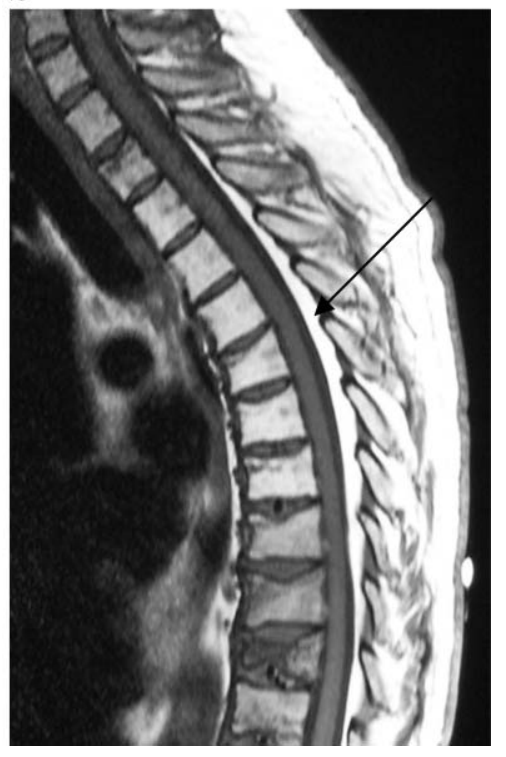

Figure $2 \mathrm{MRI}$ of midline sagittal section, T1 weighed sequence. Scans were carried out at diagnosis (a) and 6 months after resection of carcinoid (b). The arrow indicates the accumulation of fat in the epidural space from the first to the tenth thoracic vertebra with compression of the dural sac. Extended osteoporosis and compression fracture of the tenth thoracic vertebra are also evident.

transplantation, multiple sclerosis, bronchial asthma, chronic obstructive pulmonary disease, ulcerative colitis, Graves' disease and atopic dermatitis (6-14). In all these patients, the development of SEL was independent of the glucocorticoid dosage and even occurred in patients who received a prednisone dosage as low as $10 \mathrm{mg} /$ day. Time to onset of symptoms of SEL varied between 2 months and 30 years after initiation of glucocorticoid treatment. BMI and tissue sensitivity to glucocorticoids are probably important factors in the development of SEL. There seems to be a direct correlation between the concentration of the glucocorticoid receptor in a cell and the sensitivity of the cell to glucocorticoids. Obese patients might be more at risk of developing SEL during corticosteroid therapy (16). Only one case reports on SEL in hypothyroidism and

\section{a}

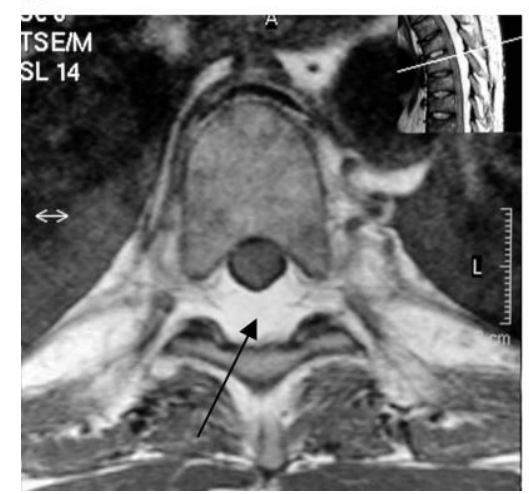

is possibly a coincidental finding (17). SEL related to endogenous Cushing's syndrome is very rare, our patient is the sixth reported case in the literature and the second on ectopic Cushing's syndrome. The etiology of the Cushing's syndrome of the five previous cases can be found in Table 1. The prevalence of SEL in endogenous hypercortisolism is unknown. A higher prevalence might be expected in patients with ectopic Cushing's syndrome because of the generally higher cortisol levels (16). Recent discoveries show that adipose tissue has metabolic and endocrine functions. The adipocyte produces several hormones and is part of an endocrine regulatory system (18). Adipose tissue is connected via the hypothalamus, by branches of the sympathetic and parasympathetic nervous system, with the autonomic nervous system. Different

\section{b}

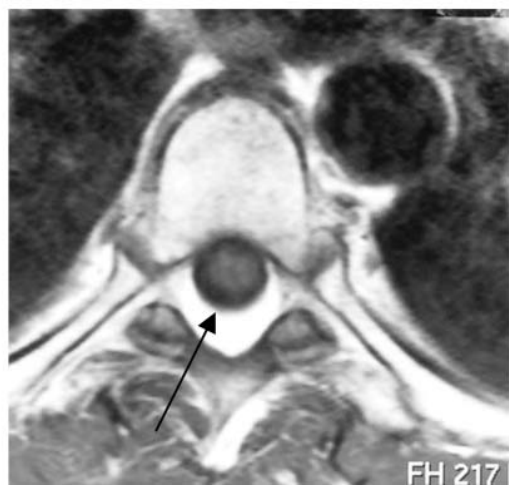

Figure $3 \mathrm{MRI}$ of transversal section, T1 weighed sequence. Scans were carried out at diagnosis (a) and 6 months after resection of carcinoid (b). The black arrow indicates the accumulation of fat in the posterior epidural space. 
Table 1 Five previous reported cases of SEL related to endogenous Cushing's disease or syndrome.

\begin{tabular}{|c|c|c|c|c|c|}
\hline Reference & Age/sex & Etiology & Symptoms & Treatment & Outcome \\
\hline Noël et al. (1) & $35 / \mathrm{M}$ & Adrenal tumor & $\begin{array}{l}\text { Bilateral Babinski, } \\
\text { Th3 sensory level }\end{array}$ & $\begin{array}{l}\text { Removal of } \\
\text { adrenal tumor }\end{array}$ & $\begin{array}{l}\text { Partial relief of neurological } \\
\text { symptoms, reduction of } \\
\text { lipomatosis on MRI }\end{array}$ \\
\hline $\begin{array}{l}\text { Dumont-Fischer } \\
\text { et al. (2) }\end{array}$ & $49 / F$ & Adrenal tumor & $\begin{array}{l}\text { Low back pain, sciatica } \\
\text { L5 nerve root }\end{array}$ & $\begin{array}{l}\text { Removal of } \\
\text { adrenal tumor }\end{array}$ & $\begin{array}{l}\text { Complete symptom relief } \\
\text { after } 4 \text { months, decrease } \\
\text { in epidural fat }\end{array}$ \\
\hline Koch et al. (3) & $36 / F$ & $\begin{array}{l}\text { Bronchial carcinoid } \\
\text { ectopic ACTH }\end{array}$ & $\begin{array}{l}\text { T6 sensory level, weakness } \\
\text { in lower extremities }\end{array}$ & $\begin{array}{l}\text { Removal of carcinoid, } \\
\text { laminectomy, steroid } \\
\text { synthesis inhibitors }\end{array}$ & $\begin{array}{l}\text { Complete symptom relief, } \\
\text { no visible epidural fat after } \\
5 \text { months }\end{array}$ \\
\hline $\begin{array}{l}\text { Benamou } \\
\text { et al. (4) }\end{array}$ & $58 / F$ & $\begin{array}{l}\text { Recurrent Cushing's } \\
\text { disease }\end{array}$ & $\begin{array}{l}\text { Low back pain, sciatica } \\
\text { left } S 1 \text { nerve root }\end{array}$ & $\begin{array}{l}\text { Op' DDD, intradural } \\
\text { corticosteroid injections }\end{array}$ & $\begin{array}{l}\text { Complete symptom relief } \\
\text { after } 6 \text { months }\end{array}$ \\
\hline $\begin{array}{l}\text { Sivakamur } \\
\text { et al. (5) }\end{array}$ & $33 / \mathrm{M}$ & Cushing's disease & $\begin{array}{l}\text { Bilateral Babinski, weakness } \\
\text { in lower extremities, } \\
\text { diminished pain perception } \\
\text { below Th8-Th9 }\end{array}$ & $\begin{array}{l}\text { Trans-sphenoidal removal } \\
\text { of pituitary, tumor, no } \\
\text { laminectomy possible }\end{array}$ & $\begin{array}{l}\text { Partial relief, muscle strength } \\
\text { regained after } 2 \text { months }\end{array}$ \\
\hline
\end{tabular}

Op' DDD, mitotane (therapy for adrenocortical carcinoma).

fat compartments (subcutaneous/intra-abdominal) are separately innervated by both branches of the sympathetic and parasympathetic system and are represented by specific autonomic motor neurons. This neuro-endocrine circuit with a feedback mechanism on the central nervous system is a possible neuro-anatomical basis for fat distribution in the body $(19,20)$. Growth of epidural fat can possibly be explained because of direct stimulation by cortisol or indirect stimulation by the autonomic nervous system.

The diagnosis of SEL is often made late, especially in patients on prolonged steroid therapy. The presenting symptoms are often mild and non-specific and can easily be mistaken for side effects of glucocorticoid therapy such as osteoporosis and myopathy $(2,7)$. Compression of the nerve roots or spinal cord causes signs of radiculopathy and myelopathy; lower back pain is often present. The thoracic and lumbar spine are most commonly affected, cervical involvement has never been reported. In addition, the thoracic spinal canal is narrower than the lumbar spinal canal so a smaller amount of fat is needed before compressive effects occur. The preferred imaging technique is MRI; the advantage of MRI over CT is that other lesions can be visualized, such as degenerative disc disease and osteoporosis with compression fractures, which can possibly be involved in the patient's symptoms (2). The traditional treatment for patients with severe neurological deficits and progressive symptoms is surgical decompression via laminectomy with debulking of the epidural fat (7). The majority of published cases show partial or complete relief of symptoms after surgery. Correction of underlying endocrinopathy in cases of Cushing's disease is imperative. Conservative management, e.g. reduction of steroid dosage and weight loss, has also been reported as being successful in mild and non-progressive cases $(6,8)$.

In conclusion, epidural localization of lipomatosis should be considered in patients with endogenous Cushing's syndrome and those who are receiving glucocorticoid therapy. Severe neurological symptoms can occur for which surgical intervention may be necessary. Screening for spinal lipomatosis in highrisk patients is possibly a useful tool for early detection.

\section{References}

1 Noël P, Pepersack T, Vanbinst A \& Allé JL. Spinal epidural lipomatosis in Cushing's syndrome secondary to an adrenal tumor. Neurology $1992 \mathbf{4 2} 1250-1251$.

2 Dumont-Fischer D, Rat AC, Saidenberg-Kermanach N, Laurent S, Cohen R \& Boissier MC. Spinal epidural lipomatosis revealing endogenous Cushing's syndrome. Joint, Bone, Spine: Revue du Rhumatisme $200269222-225$.

3 Koch CA, Doppman JL, Watson JC, Patronas NJ \& Nieman LK. Spinal epidural lipomatosis in patient with the ectopic corticotropin syndrome. New England Journal of Medicine 1999341 1399-1400.

4 Benamou PH, Hilliquin P, Chemla N, Chevrot A, Cormier C \& Menkès CJ. Epidural lipomatosis not induced by corticosteroid therapy. Revue du Rhumatisme 199663 207-212.

5 Sivakamur K, Sheinart K, Lidov M \& Cohen B. Symptomatic spinal epidural lipomatosis in a patient with Cushing's disease. Neurology $1995 \mathbf{4 5} 2281-2283$.

6 Haddad SF, Hitchon PW \& Godersky JC. Idiopathic and glucocorticoid-induced spinal epidural lipomatosis. Journal of Neurosurgery 199174 38-42.

7 Zenntner J, Buchbender K \& Vahlensieck M. Spinal epidural lipomatosis as a complication of prolonged corticosteroid therapy. Journal of Neurosurgical Sciences 199539 81-85.

8 Chapman PH, Martuza RL, Poletti CE \& Karchmer W. Symptomatic spinal epidural lipomatosis associated with Cushing's syndrome. Neurosurgery 19818 724-727.

9 Kaplan JG, Barasch E, Hirschfeld A, Ross L, Einberg K \& Gordon M. Spinal epidural lipomatosis a serious complication of iatrogenic Cushing's syndrome. Neurology 198939 1031-1034.

10 Roy-Camille R, Mazel CH, Husson JL \& Saillant G. Symptomatic spinal epidural lipomatosis induced by a long term steroid treatment. Spine $1991 \mathbf{1 6} 1365-1371$.

11 Zampella EJ, Duvall ER, Sekar BC, Langford KH, Epstein AE, Kirklin JK \& Morawetz RB. Symptomatic spinal epidural lipomatosis as a complication of steroid immunosuppression in cardiac transplant patients. Journal of Neurosurgery $1987 \mathbf{6 7} 760-764$.

12 Lipson SJ, Naheedy MH, Kaplan MM \& Bienfang DC. Spinal stenosis caused by epidural lipomatosis in Cushing's syndrome. New England Journal of Medicine 1980336. 
13 Russell NA, Belanger G, Benoit BG, Latter DN, Finestone DL \& Armstrong GW. Spinal epidural lipomatosis a complication of glucocorticoid therapy. Canadian Journal or Neurological Science $198411383-386$

14 Andress HJ, Schürmann M, Heuck A, Schmand J \& Lob G. A rare case of osteoporotic spine fracture associated with epidural lipomatosis causing paraplegia following long-term cortisone therapy. Archives of Orthopaedic and Trauma Surgery 2000120 484-486.

15 Sandberg DI \& Lavyne MH. Symptomatic spinal epidural lipomatosis after local epidural corticosteroid injections. Case report. Neurosurgery $199945162-165$.

16 Koch CA, Dopmann JL, Patronas NJ, Niemann LK \& Chrousos GP. Do glucocorticoids cause spinal epidural lipomatosis? When endocrinology and spinal surgery meet. Trends in Endocrinology and Metabolism 20003 86-90.

17 Toshniwal PK \& Glick RP. Spinal epidural lipomatosis report of a case secondary to hypothyroidism and review of the literature. Journal of Neurology $1987234172-176$.
18 Jazet IM, Pijl H \& Meinders AE. Adipose tissue as an endocrine organ impact on insulin resistance. Netherlands Journal of Medicine $20036194-211$

19 Fliers E, Romijn JA, Sauerwijn HP, Kalsbeek A, Kreier F \& Buijs RM. Vetweefsel een geïnnerveerde endocriene klier. Nederlands Militair Geneeskundig Tijdschrift $2002 \quad 146$ 1976-1979.

20 Kreier F, Yilmaz A, Kalsbeek A, Romijn JA, Sauerwein HP, Fliers E \& Buijs RM. Hypothesis. Shifting the equilibrium from activity to food leads to autonomic unbalance and the metabolic syndrome. Diabetes 200352 2652-2656.

Received 13 July 2004

Accepted 13 September 2004 